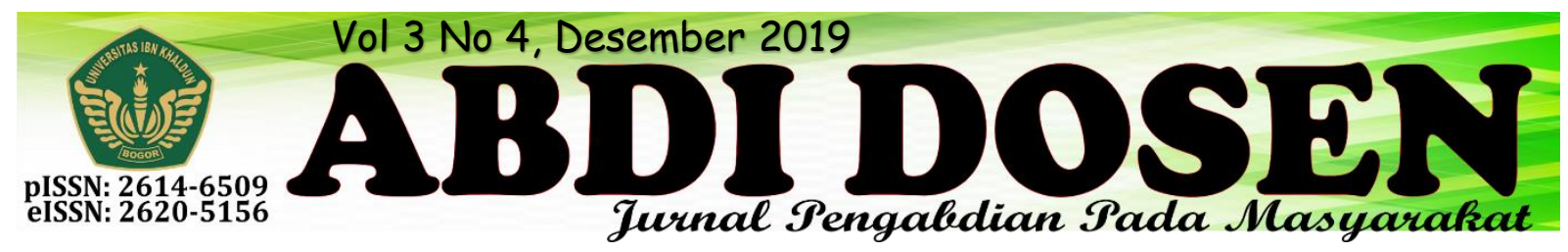

\title{
PEMANFAATAN MEDIA SOSIAL UNTUK PEMASARAN PRODUK HOME INDUSTRY TAS DI KAMPUNG SINDANG PALA DESA CIBENING KECAMATAN PAMIJAHAN KABUPATEN BOGOR
}

\author{
Eko Hadi Purwanto ${ }^{1}$, Aldi Rianto, Annisa Yulita Sari ${ }^{2}$ \\ ehpurwa@gmail.com \\ Fakultas Teknik Universitas Ibn Khaldun ${ }^{1}$, Mahasiswa KKN Kelompok 38 Tahun $2018^{2}$
}

\begin{abstract}
ABSTRAK
Media sosial telah menjadi pilar utama dalam penyampaian informasi. Media Sosial dapat dipergunakan untuk memperkenalkan sekaligus memasarkan produk yang kita miliki. Dalam kata lain, media sosial dipergunakan sebagai sarana masyarakat dalam melakukan jual beli produk atau jasa. Tujuan memasarkan produk home industry tas melalui media sosial yaitu untuk meningkatkan Omset penjualan, mudahnya produk tas dikenal banyak orang, menambah minat konsumen di luar Desa Cibening dan mampu bersaing dengan produk dalam negeri lainnya. Penggunaan media sosial merupakan sarana yang tepat untuk memasarkan produk home industry tas, karena familiarnya penggunaan media sosial saat ini di kalangan masyarakat. Pemasaran melalui media sosial membentuk peluang pasar, membangun dan mempertahankan hubungan dengan pelanggan secara efisien. Melalui media sosial dapat terjalin komunikasi yang interaktif antara konsumen dengan pelaku bisnis, misalnya saja melalui direct message (Instagram) dan jaringan pribadi (Whatsapp) tanpa harus mengeluarkan biaya transportasi. Jika komunikasi mampu terjaga dengan baik maka dapat meningkatkan loyalitas konsumen. Jika loyalitas konsumen meningkat maka omset dan profit meningkat. Produk home industry tas ini merupakan produk yang mengutamakan kualitas dan kenyamanan penggunanya namun dengan harga terjangkau.
\end{abstract}

Kata Kunci : Media Sosial, Pemasaran, Produk Home Industry, Produk Tas

\section{PENDAHULUAN}

Berdasarkan hasil observasi dan analisis Desa Cibening merupakan salah satu Desa yang berada di wilayah Kecamatan Pamijahan, Kabupaten Bogor.

$$
\text { Penggunaan Media Sosial }
$$
berkembang sangat pesat di Indonesia, sehingga para pemasar menggunakan media sosial sebagai salah satu alat pemasaran. Pemasaran produk home industry tas melalui media sosial dilakukan karena kami sebagai Mahasiswa dan Mahasiswi
Universitas Ibn Khaldun Bogor yang sedang melaksanakan tugas Kuliah Kerja Nyata (KKN) di Kampung Sindangpala Desa Cibening Kecamatan Pamijahan Kabupaten Bogor, melihat bahwa ada potensi usaha warga namun minim pemberdayaan dan pemanfaatan teknologi yang sudah marak bahkan familiar saat ini. Bukan hanya familiar namun sebenarnya mudah juga untuk digunakan. Teknologi tersebut adalah Media Sosial. Sebut saja 
Instagram dan Whatsapp merupakan dua media sosial yang paling banyak digunakan oleh kalangan masyarakat. Tujuan pemanfaatan media sosial disini adalah untuk meningkatkan omset penjualan produk bagi pemilik usaha.

\section{Keadaan Geografis}

Desa Cibening berada di wilayah Kabupaten Bogor tepatnya di Kecamatan Pamijahan dengan luas wilayah 346.920 Ha. Jarak tempuh Desa Cibening ke Pusat Kecamatan adalah $5 \mathrm{Km}$, dan jarak tempuh ke Pusat Otoda adalah $27 \mathrm{Km}$. Desa Cibening terbagi menjadi 4 Dusun, 9 Rukun Warga, 38 Rukun Tetangga, 21 Kampung. Adapun dusun-dusun tersebut adalah sebagai berikut :

Dusun 1 : RW 01, RW 02, dan RW 09 (11 RT dan 6 Kampung)

Dusun 2 : RW 03 dan RW 04 (9 RT dan 2 Kampung)

Dusun 3 : RW 05 dan RW 08 (10 RT dan 5 Kampung)

Dusun 4 : RW 06 dan RW 07 (8 RT dan 8 Kampung)

Adapun batas wilayah Desa Cibening adalah sebagai berikut :

\begin{tabular}{|c|c|c|}
\hline No. & Arah & Berbatasan \\
\hline 1 & Utara & $\begin{array}{c}\text { Desa Ciaruteun } \\
\text { Udik, Kecamatan } \\
\text { Ciampea }\end{array}$ \\
\hline 2 & Timur & $\begin{array}{c}\text { Desa Tapos, } \\
\text { Kecamatan } \\
\text { Tenjolaya }\end{array}$ \\
\hline 3 & Selatan & $\begin{array}{c}\text { Desa Gunung } \\
\text { Bunder Satu }\end{array}$ \\
\hline 4 & Barat & $\begin{array}{c}\text { Desa Gunung } \\
\text { Menyan }\end{array}$ \\
\hline
\end{tabular}

\section{Kondisi Masyarakat}

Jumlah penduduk desa cibening sampai dengan bulan april 2008 tercatat sebanyak 13.709 jiwa, dimana jumlah laki- laki sekitar 7.006 jiwa dan jumlah perempuan sebanyak 6.703 jiwa.

Kemudian kondisi penduduk berdasarkan agama yang dianutnya adalah sebagai berikut :

\begin{tabular}{|l|l|l|}
\hline No & Agama & Jumlah \\
\hline 1. & Islam & $\begin{array}{l}12.625 \\
\text { orang }\end{array}$ \\
\hline 2. & Kristen Protestan & 10 orang \\
\hline 3. & Katolik & - \\
\hline 4. & Budha & 2 orang \\
\hline 5. & Hindu & - \\
\hline 6. & Konghucu & - \\
\hline
\end{tabular}

Mata pencaharian penduduk Desa Cibening adalah sebagai berikut :

\begin{tabular}{|c|l|c|}
\hline No & \multicolumn{1}{|c|}{ Mata Pencaharian } & Jumlah \\
\hline 1. & Petani & $\begin{array}{c}1.558 \\
\text { orang }\end{array}$ \\
\hline 2. & Pedagang & 898 orang \\
\hline 3. & Pegawai Negeri & 48 orang \\
\hline 4. & Pegawai swasta & - \\
\hline 5. & Karyawan & 427 orang \\
\hline 6. & TNI/Polri & 3 orang \\
\hline 7. & Pensiun/Purnawirawan & 34 orang \\
\hline 8. & Tukang Bangunan & 52 orang \\
\hline 9. & Tukang Las & 40 orang \\
\hline 10. & Tukang Ojek & 45 orang \\
\hline 11. & Buruh Tani/Kebun & $\begin{array}{c}1.046 \\
\text { orang }\end{array}$ \\
\hline 12. & Buruh pabrik & 60 orang \\
\hline 13 & Buruh Bangunan & 289 orang \\
\hline 14 & Buruh Serabutan & - \\
\hline 15 & Pengrajin & 7 orang \\
\hline 16 & Penjahit & 7 orang \\
\hline 17 & Sopir Angkot & 50 orang \\
\hline 18 & Sopir Pribadi & 10 orang \\
\hline 19 & Lain Lain & - \\
\hline Ada & beberapa aspek yang dapat \\
\hline
\end{tabular}
menggambarkan kondisi masyarakat di Kampung Sindang Pala, diantaranya adalah: 


\section{Aspek Pendidikan}

Pendidikan merupakan hal yang sangat penting di dalam kehidupan. Dari hasil observasi dan pengamatan selama 1 bulan di salah satu Desa yang ada di Kecamatan Pamijahan yaitu Desa Cibening terlihat banyak sekali lembaga pendidikan yang ada disana. Mulai dari jenjang PAUD/TK/TPQ/RA, MI/SD, MTS/SMP, MA/SMA, sehingga bisa dikategorikan bahwa di Desa Cibening ini tingkat pendidikannya sudah cukup baik, selain itu jarak dari rumah ke sekolah tidak begitu jauh sehingga anak-anak disana cukup mudah untuk menempuh akses perjalanan dari rumah mereka ke sekolah.

Selain itu dapat dilihat juga pendidikan di salah satu kampung yang kami jadikan sebagai tempat untuk melaksanakan beberapa program kerja kami disana yaitu Kp. Sindang Pala Desa Cibening Kecamatan Pamijahan Kabupaten Bogor tepatnya di RT 04 RW 04. Kampung Sindang Pala terdapat tiga lembaga pendidikan diantaranya ada Yayasan TPQ Hj. Siti Haroh, PAUD Az-Zahra, dan SDN Cibening 03. Dilihat dari segi lembaga pendidikannya sudah cukup baik, meskipun masih ada beberapa sarana dan prasarana yang kurang memadai. Dari segi tenaga pendidiknya rata-rata pendidikan terakhirnya adalah S1 dan sudah ada di beberapa lembaga yang sudah menjadi PNS, namun masih ada lembaga pendidikan yang masih kurang SDM nya. Melihat kondisi sekitar rata-rata anak-anak yang ada di Kp. Sindang Pala semua mengenyam bangku pendidikan, namun hanya sampai di tingkat SMP-SMA saja. Selain itu masih banyak anak-anak yang mengalami kesulitan belajar contohnya seperti, sulitnya membaca, menulis dan kurangnya pemahaman atas materi yang telah disampaikan oleh guru di sekolah. Ada beberapa faktor yang menyebabkan hal tersebut terjadi diantarnya adalah, kurangnya perhatian orang tua terhadap waktu belajar anak, dan kurangnya konsentrasi siswa pada saat berada di sekolah dalam menerima materi pelajaran.

\section{Aspek Ekonomi}

Perekonomian yang ada di Desa Cibening rata-rata mata pencahariannya adalah berjualan, berkebun, guru dan buruh harian lepas. Dari semua mata pencaharian yang ada penghasilan yang didapatkan tidak menentu, namun cukup untuk memenuhi kebutuhan sehari-hari. Tidak jauh berbeda di Kampung Sindang Pala Desa Cibening Kecamatan Pamijahan Kabupaten Bogor, mata pencaharian warganya adalah dengan berjualan, berkebun, guru dan tukang ojek. Adapun satu warga khususnya di RT 02 RW 04 yang mata pencahariannya yaitu dengan memproduksi tas. Namun usaha ini hanya dijalankannya sendiri tanpa adanya karyawan, dan ia hanya memasarkan tas secara door-to-door kepada rekan dekat dan menerima pesanan dengan sistem order receive. Selain itu di Kp. Sindang Pala juga banyak warga yang bekerja di kebun salah satu contohnya adalah banyaknya kebun pohon jambu, dimana buah jambu jika sudah panen nantinya akan dikirim ke pasar induk yang ada di Jakarta.

\section{Aspek Kesehatan}

Kesehatan merupakan salah satu aspek penting yang ada di dalam kehidupan. Melihat kondisi yang ada di Desa Cibening sarana dan prasarana yang ada untuk kesehatan cukup memadai karena adanya beberapa klinik yang ada dipinggir jalan sekitar Desa Cibening.

Namun untuk sarana dan prasarana pelayanan kesehatan seperti puskesmas sangat jauh. Terutama dari Kampung Sindang Pala, jarak tempuhnya tidak dapat di akses dengan hanya berjalan kaki saja, 
namun harus menggunakan layanan angkutan umum. Tetapi seperti yang sudah dijelaskan sebelumnya bahwa untuk layanan kesehatan berupa klinik dari Kampung Sindang Pala cukup terjangkau jaraknya yaitu terletak dipinggir jalan sekitar Desa Cibening.

\section{Aspek Lingkungan}

Desa Cibening merupakan salah satu desa yang padat penduduk. Secara umum sosial politik serta ketentraman dan ketertiban di wilayah Desa Cibening cukup terkendali. Dalam hal ini kehidupan berpolitik warga masyarakat dapat tersalurkan sesuai dengan aspirasi seiring dengan bergulirnya repormasi dan banyaknya partai politik yang berkembang sekarang ini.

Melihat kondisi yang ada sulitnya akses menemukan satu kampung ke kampung yang lainnya. Artinya tidak ada tanda jalan agar orang-orang yang berlalu lintas dapat dengan mudah untuk mencari kampung yang ada di Desa Cibening, termasuk Kampung Sindang Pala. Sehingga sama sekali tidak ada tanda yang menunjukkan apa nama kampung tersebut.

Ketika melihat kondisi lingkungan yang ada di Kampung Sindang Pala Desa Cibening khususnya RW 04 kebersihannya masih kurang terjaga. Masih banyak sampah berserakan di pinggir jalan dan masih menjadi kebiasaan dalam membuang sampah sembarangan serta tidak adanya tempat sampah di satu titik di setiap RT.

Selain itu dalam segi kerukunan warga yang ada di Kampung Sindang Pala, dimana jarak dari satu RT ke RT yang lain sangat dekat. Tetapi kurang adanya kerukunan antar RT. Ketika akan dilaksankan kegiatanpun masih sulit untuk menyatukan antar RT dalam satu tempat.
Melihat kondisi pemuda-pemudi yang ada di setiap RT nya pun kurang terjalin dengan baik, masih kurang baik dalam berprilaku dan pergaulan, dan masih kurangnya pemahaman dalam menerapkan ilmu agama di dalam kehidupan sehari-hari.

Dalam hal ini terlihat kurangnya pemahaman warga terhadap peraturan yang ada dan pemahaman mengenai bagaimana bahayanya sampah yang dibuang sembarangan jika tidak diatasi, dampak dari kurangnya bersosialisasi dalam menciptakan kerukunan warga serta kurangnya pemahaman akan pentingnya dokumentasi kependudukan yang dimiliki warga. Mayoritas warga di Kampung Sindang Pala sudah memiliki dokumentasi kependudukan, namun masih belum lengkap. Contohnya seperti anak yang baru lulus sekolah dan warga usia lanjut yang belum memiliki KTP, adapun yang sudah menikah, KK masih menyatu dengan orangtua. Hal tersebut disebabkan karena jarak tempuh yang jauh dan memerlukan biaya transportasi yang tidak sedikit, lamanya proses pelayanan dan data pendukung yang kurang sehingga tidak cukup satu kali datang ke instansi terkait, rendahnya pemahaman warga usia lanjut akan pentingnya surat dan dokumentasi kependudukan serta kurangnya partisipasi anggota keluarga untuk mengarahkan bahwa usia lanjut perlu memiliki KTP, sosialisasi yang tidak merata dan tidak adanya penggunaan mobil keliling untuk pelayanan yang jauh dari kantor Dinas Kependudukan Catatan Sipil atau pelaksanaan pelayanan jemput bola serta kurangnya pemahaman penduduk mengenai pelaporan peristiwa kependudukan kepada instansi terkait. 


\section{METODE PENGABDIAN}

Tahapan pelaksanaan untuk kegiatan ini sebagaimana terlihat pada bagan sebagai berikut :

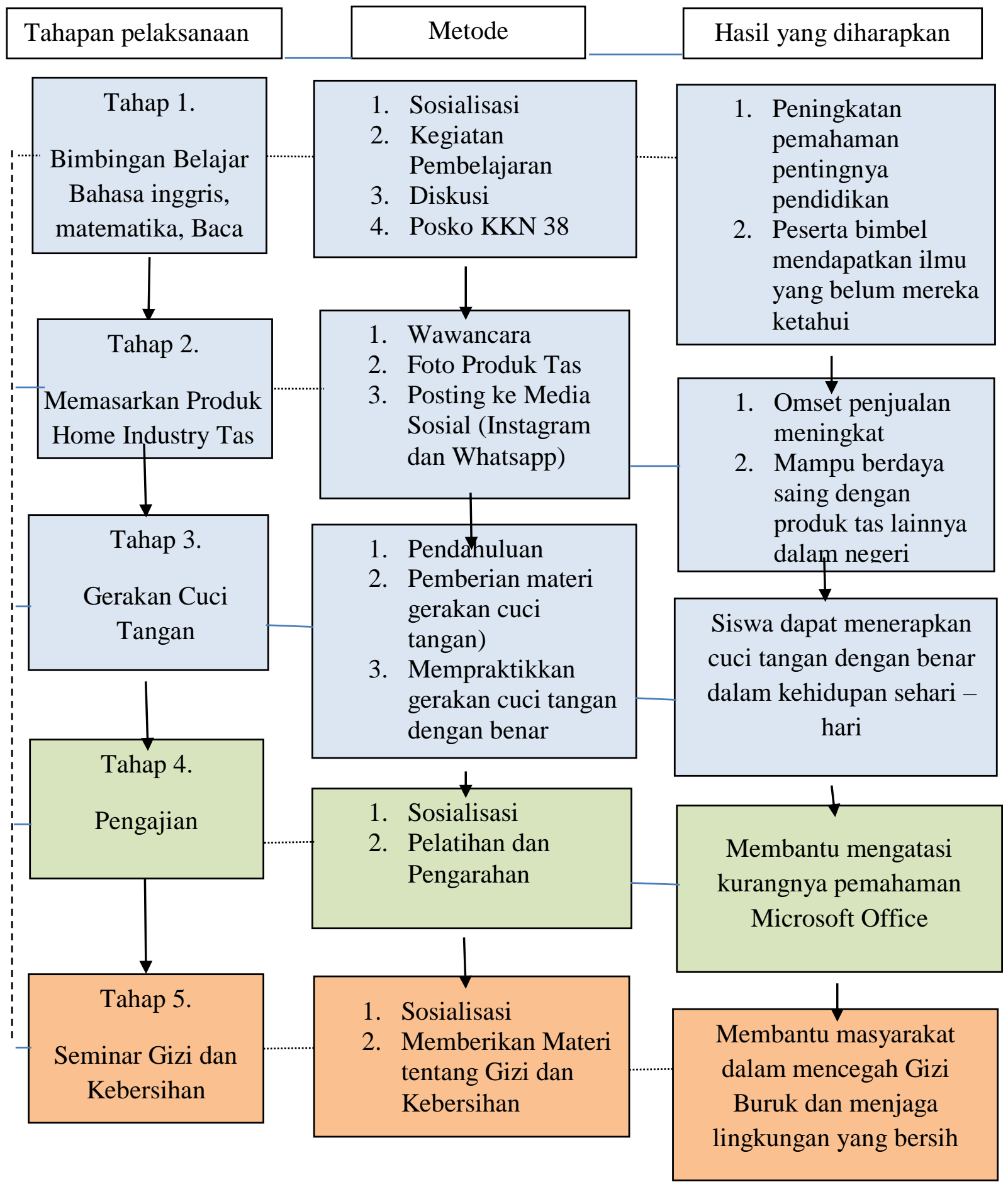


Jadwal Kegiatan

\begin{tabular}{|c|c|c|c|c|c|}
\hline \multirow{2}{*}{ No. } & \multirow{2}{*}{ Kegiatan } & \multicolumn{4}{|c|}{ Bulan } \\
\hline & & 1 & 2 & 3 & 4 \\
\hline 1 & Penyusunan Rencana kegiatan & & & & \\
\hline 2 & Penyusunan Struktur Kelompok KKN & & & & \\
\hline 3 & Sosialisasi rencana kegiatan & & & & \\
\hline 4 & Mengajar di Yayasan TPQ Hj. Siti Haroh & & & & \\
\hline 5 & Mengajar di SDN Cibening 03 & & & & \\
\hline 6 & Bimbingan Belajar & & & & \\
\hline 7 & Pengajian & & & & \\
\hline 8 & Memasarkan Produk Home Industri Tas & & & & \\
\hline 9 & Gerakan Cuci Tangan & & & & \\
\hline 10 & Penyuluhan Dokumentasi Kependudukan & & & & \\
\hline 11 & Ikut Berpartisipasi Merayakan HUT RI & & & & \\
\hline 12 & Gerakan Menabung di Usia Dini & & & & \\
\hline 13 & Pelatihan TIK & & & & \\
\hline 14 & Seminar Gizi dan Kebersihan & & & & \\
\hline 15 & Senam Sehat & & & & \\
\hline 16 & Pembangunan Fasilitas Umum & & & & \\
\hline 17 & Gotong Royong & & & & \\
\hline 18 & Pemetaan Desa Cibening & & & & \\
\hline 19 & $\begin{array}{l}\text { Pelaksanaan Lomba anak-anak dalam rangka } \\
\text { perpisahan kkn }\end{array}$ & & & & \\
\hline 20 & Penyusunan laporan & & & & \\
\hline
\end{tabular}

\section{Metode Pendekatan}

Pendekatan yang digunakan dalam kegiatan ini adalah :

a. Pendekatan religious, yaitu pendekatan dengan cara bergabung kedalam majlis ta'lim, baik majlis ta'lim ibu-ibu maupun majlis ta'lim remaja.

b. Pendekatan Organisasi, yaitu keyakinan bahwa keefektifan organisasi tidak dapat dirumuskan karena ada perbedaan pandangan, pendekatan organisasi dilakukan untuk mempermudah pengenalan kami kepada warga Desa Cibening.

c. Pendekatan Kekerabatan, artinya bahwa pembinaan yang dilakukan senantiasa dikaitkan dalam rangka meningkatkan kesadaran akan pentingnya mengetahui unsur pemetaan Desa Cibening.

d. Pendekatan berdasarkan karakter masyarakat, yaitu pembinaan yang dilakukan akan disesuaikan dengan karakter masyarakat setempat, sehingga masyarakat dapat berpartisipasi langsung terhadap kegiatan-kegiatan yang akan dilaksanakan.

\section{Partisipasi Masyarakat dalam}

\section{Pelaksanaan Program}

Partisipasi masyarakat yang dapat dilakukan dalam kegiatan ini adalah sebagai berikut :

a. Mempersiapkan warga untuk melakukan kegiatan yang telah telah direncanakan. 
b. Mempersiapkan tempat untuk pelaksanaan kegiatan seminar kesehatan dan kebersihan.

c. Memberikan bantuan moril.

d. Memberikan kritik dan saran terhadap keberlangsungan program.

\section{Langkah Evaluasi}

a. Evaluasi masukan meliputi pertimbangan tentang sumber dan strategi yang diperlukan untuk mencapai tujuan terlaksananya program. Informasi-informasi yang tekumpul selama tahap penilaian hendaknya dapat digunakan untuk

\section{REALISASI PROGRAM}

Dalam pelaksanaan kegiatan Kuliah Kerja Nyata (KKN) Tematik Terintegrasi Universitas Ibn Khaldun Bogor di Kampung Sindang Pala, Desa Cibening, Kecamatan Pamijahan, Kabupaten Bogor

Kami membuat beberapa rangkaian program kerja yang Alhamdulilah berjalan dengan lancar sesuai dengan, diantaranya :

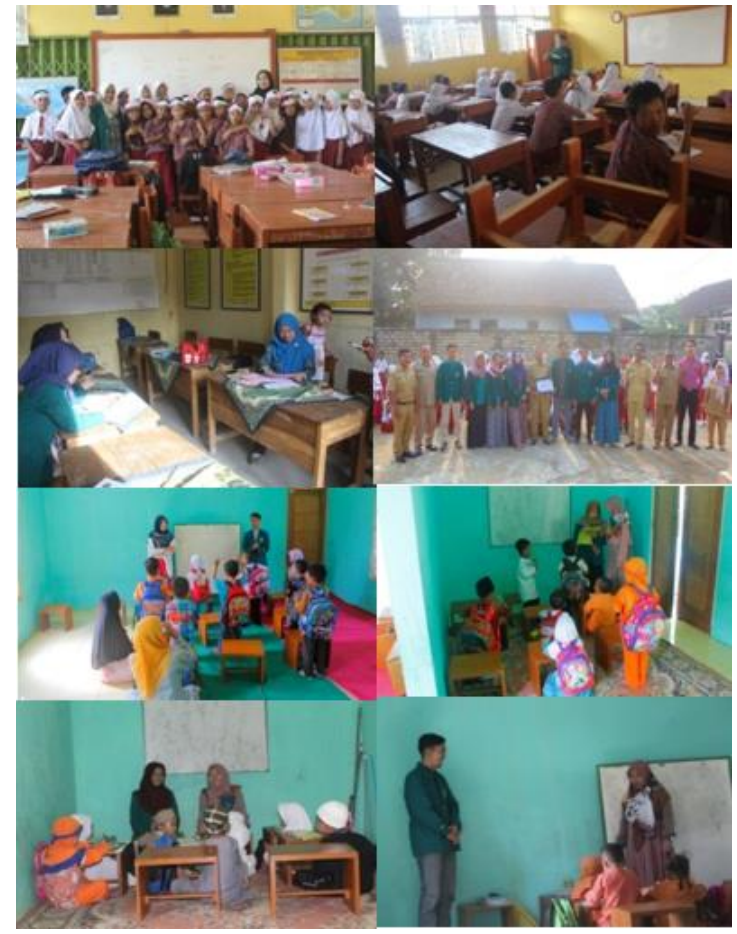

a. Kegiatan Belajar mengajar dibeberapa sekolah (SDN dan TPQ) menentukan sumber dan strategi di dalam keterbatasan dan hambatan yang ada.

b. Evaluasi proses, yang terkait dengan perencanaan, pelaksanaan dan monitoring kegiatan. Evaluasi proses akan dilakukan setiap kegiatan secara internal.

c. Evaluasi hasil, yang akan dilakukan setelah kegiatan dilaksanakan. Evaluasi hasil ditujukan untuk menguji pemahaman masyarakat tentang pentingnya unsur peta dan kesehatan

Kegiatan mengajar ini bertujuan untuk mengaplikasikan ilmu yang didapat di kampus. Selain itu kegiatan mengajar dilakukan karena untuk membantu guru-guru di sekolah. Kegiatan mengajar di SDN Cibening 03 dilakukan setiap hari Senin-Kamis terhitung sejak tanggal 09 Agustus 2018 s.d 27 Agustus 2018 dimana pada tanggal tersebut dilakukan mulai dari sosialisasi ke sekolah, , kegiatan upacara rutin setiap hari Senin, kegiatan belajar mengajar, upacara 17, Agustus, perlombaan hingga penutupan.

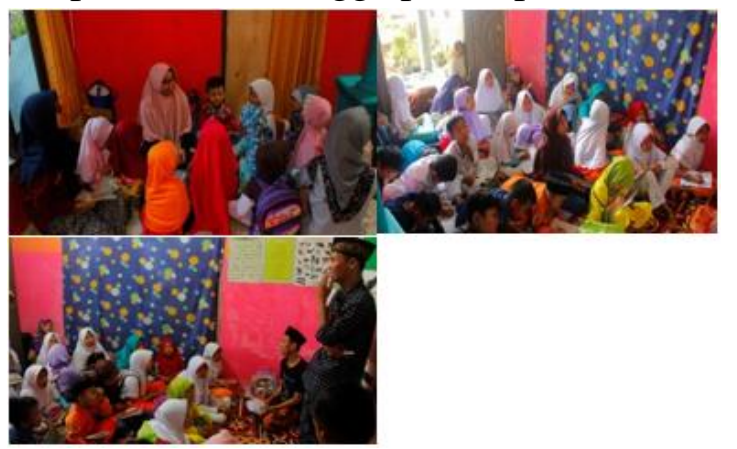

b. Kegiatan Bimbingan belajar (Bahasa Inggris, Matematika, Baca Tulis Alqur'an dan Calistung). Bimbingan Belajar ini dilaksanakan setiap 3x seminggu pada hari selasa, rabu dan 
kamis, pukul 16.30 s.d 17.30. Kegiatan ini bermanfaat untuk membantu anakanak di sekitar Kampung Sindang Pala.

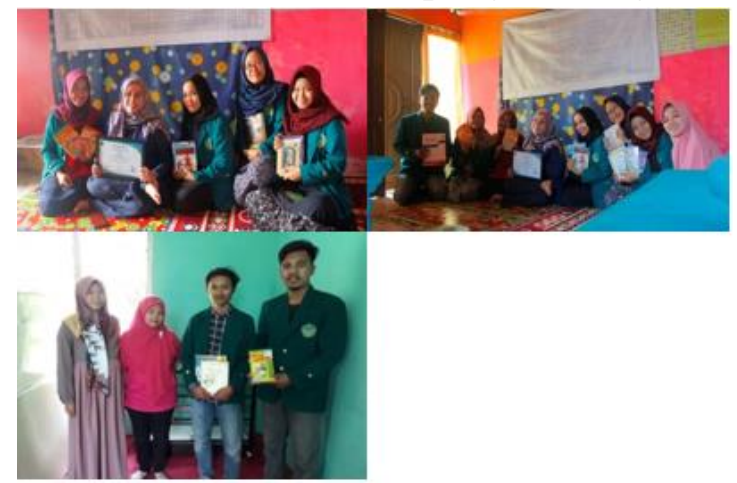

c. Taman Baca

Program taman baca bertujuan untuk memberikan fasilitas bagi anak-anak untuk menambah wawasan dan menambah minat memabaca pada anak.

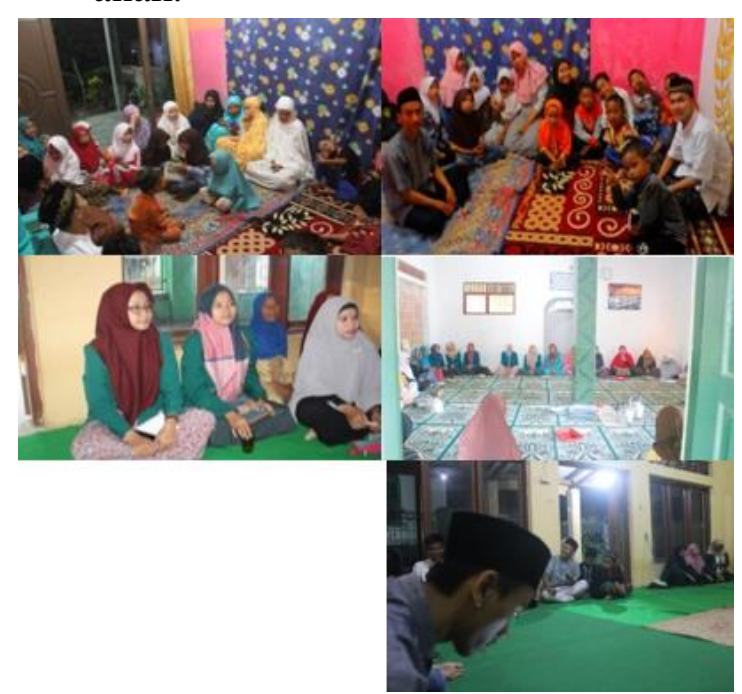

d. Kegiatan pengajian terdiri dari pengajian rutin anak-anak, pengajian mingguan ibu-ibu, dan pengajian mingguan remaja. Adapun tempat untuk pengajian rutin anak-anak diselenggarakan di posko KKN tematik terintegrasi kelompok 38 pada pukul 18.30 s.d 19.30 , pengajian ibu-ibu dilaksanakan setiap 2x seminggu pada hari jum'at di majlis ta'lim al-a'la tiap pukul 07.00 s.d 09.30 WIB dan pada hari minggu dimushola RT 04 pukul 07.00 s.d 09.30 WIB dan pengajian pemuda atau pemudi dilaksanakan di majlis ta'lim al-a'la pukul 20.00 s.d 21.30 WIB.

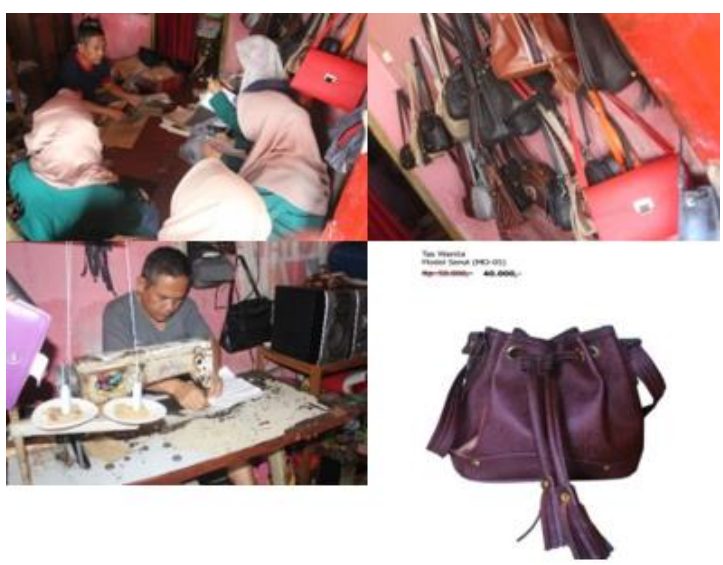

e. Memasarkan Produk Home Industry Tas

Dalam kegiatan memasarkan produk home industri ini untuk membantu produsen dalam memasarkan produknya. Kegiatan ini dilakukan karena produsen yang bersangkutan tidak memiliki wadah untuk mempromosikan produk tas tersebut.

Pemasaran dilakukan melalui media sosial Instagram dan Whatsapp. Tata caranya yaitu produk yang telah selesai difoto kemudian diupload. Untuk whatsapp kami lakukan pada akun masing-masing anggota KKN yang terlibat sedangkan untuk instagram, kami telah membuat akun khusus dengan nama 38_collection. Waktu pemasaran yaitu setiap hari mulai pukul 08.00 WIB s.d 20.00 WIB. Dalam realisasinya pemasaran tidak hanya dilakukan di media sosial, akan tetapi secara langsung seperti kepada rekan kerja dan keluarga.
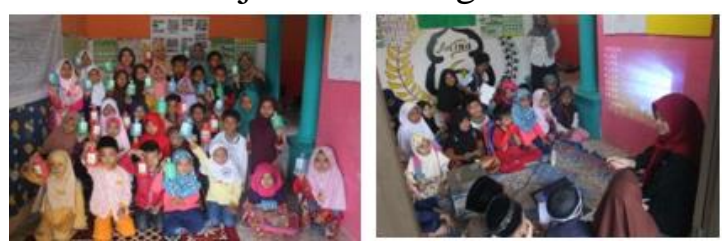

f. Gerakan Menabung di Usia Dini

Gerakan menabung di usia dini adalah suatu program yang diadakan dalam 
membangun kesadaran anak akan pentingnya menabung di usia dini.

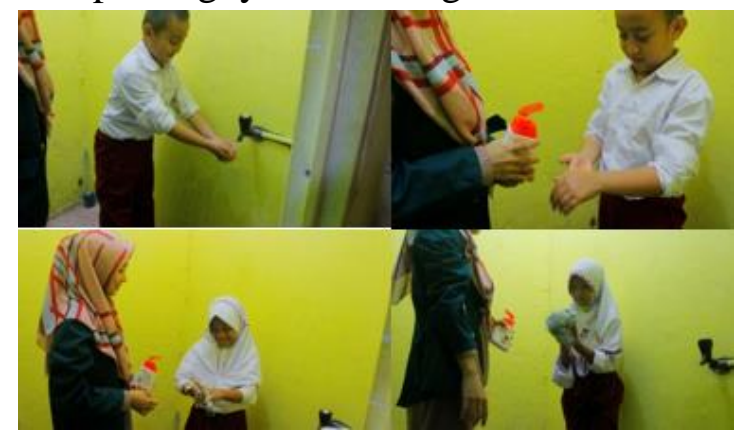

g. Gerakan Cuci Tangan Pakai Sabun

Kegiatan ini dilakukan oleh siswa/i SDN Cibening 03 kelas 1 dan 4. Yang bertujuan agar siswa/i SDN Cibening 03 mengetahui pentingnya mencuci tangan menggunakan sabun dan apa dampak dari tidak mencuci tangan sebelum dan sesudah makan. Kegiatan ini pun dapat mengajarkan siswa/i cara mencuci tangan dengan baik dan benar.
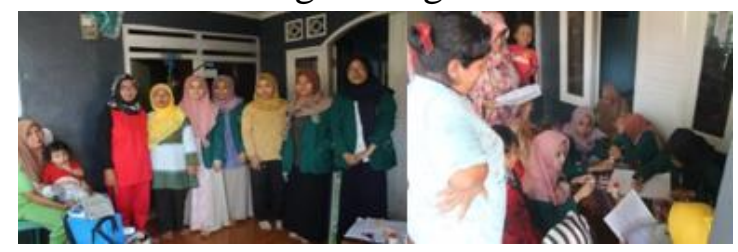

\section{h. Berpartisipasi Dalam Kegiatan Posyandu}

Kegiatan ini dilakukan di RT 03 yang bertempat di Rumah Ibu Titin salah satu kader Posyandu. Yang melibatkan bayi, batita, balita, ibu hamil, dan lansia. Kegiatan yang dilakukan di posyandu antara lain ; pemberian vitamin A, ukur berat badan, ukur tinggi badan, dan tensi darah.

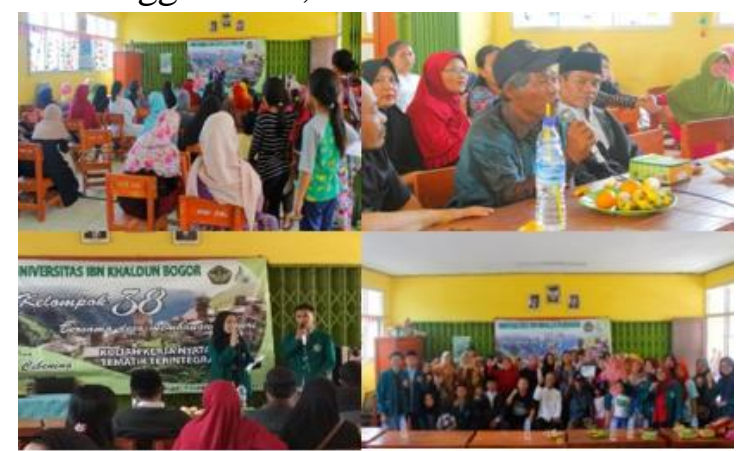

\section{i. Penyuluhan Gizi}

Kegiatan ini di lakukan oleh ibu - ibu RW 04 Kampung Sindang Pala Desa Cibening Kecamatan Pamijahan. Yang bertujuan agar ibu - ibu mengetahui pola makan yang seimbang. Dan dapat mengetahui penyakit yang berkaitan dengan gizi.

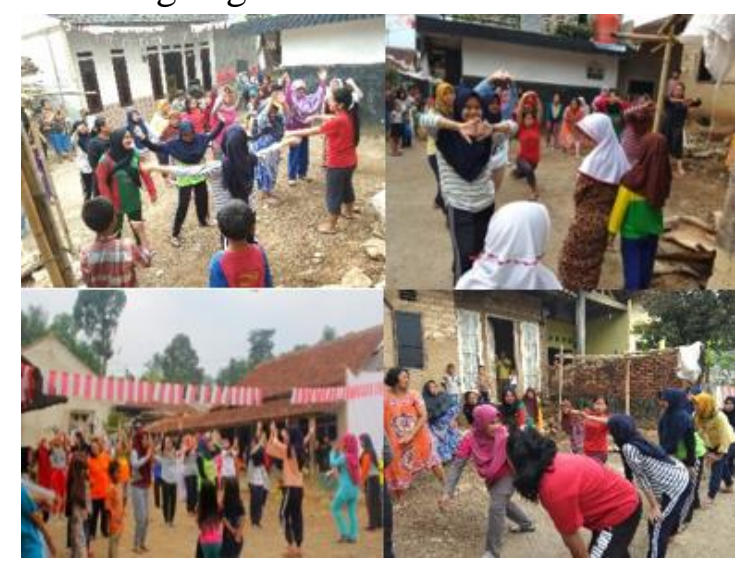

\section{j. Senam Sehat}

Kegiatan ini di lakukan oleh RT 03 dan 04 Kampung Sindang Pala Desa Cibening Kecamatan Pamijahan. Bertujuan untuk menambah kebugaran tubuh dan menyambung silaturahmi antar warga RW $04 \mathrm{Kp}$. Sindang Pala.

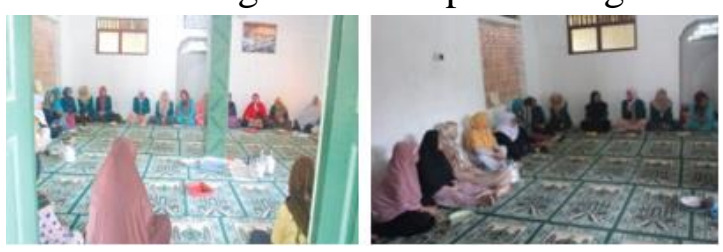

\section{k. Penyuluhan Dokumentasi}

\section{Kependudukan}

Kegiatan ini ditujukan kepada ibu - ibu yang mengikuti pengajian rutin di RW 04. Kegiatan penyuluhan ini bertujuan untuk menyadarkan warga tentang pentingnyadokumentasi kependudukan seperti Kartu Tanda Penduduk (KTP), Kartu Keluarga (KK), Akta Kelahiran, dan Buku Nikah. 


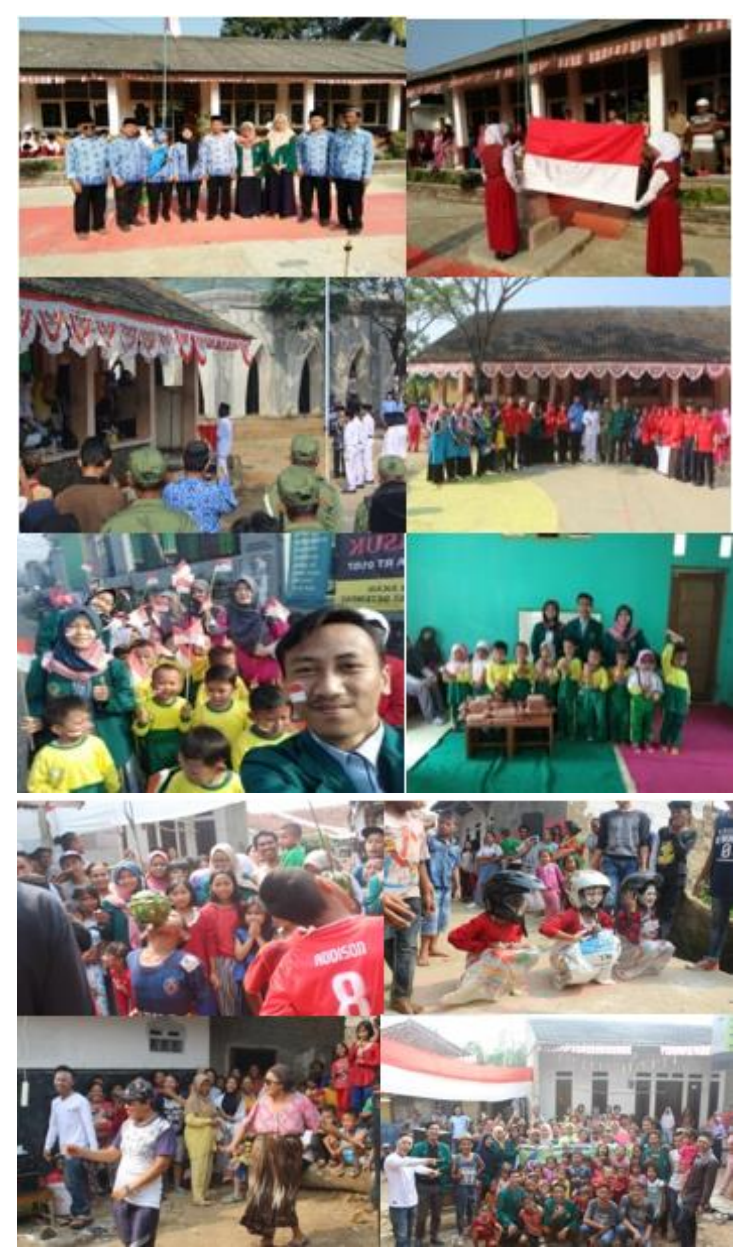

l. Kegiatan Perayaan HUT RI

Kegiatan perayaan HUT RI ini dilakukan di 3 tempat yaitu di SDN 03 Cibening, TPQ Hj. Siti Haroh dan RT 04.

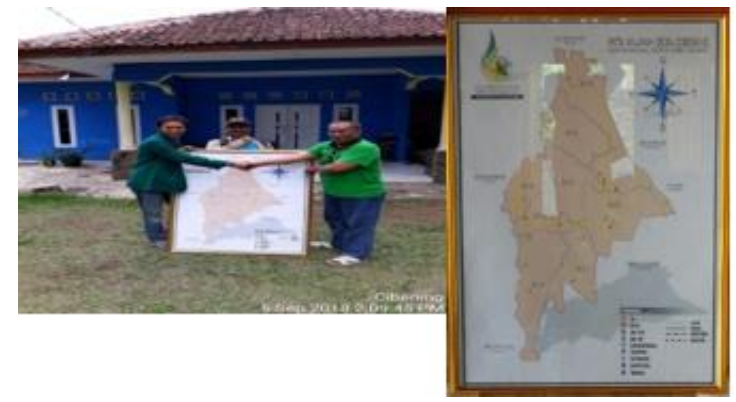

m. Pemetaan Desa Cibening

Pemetaan ini bertujuan untuk memperbarui peta yang sebelumnya sudah ada di Kantor Desa. Kegiatan ini sebagai bentuk apresiasi kami terhadap Desa Cibening.
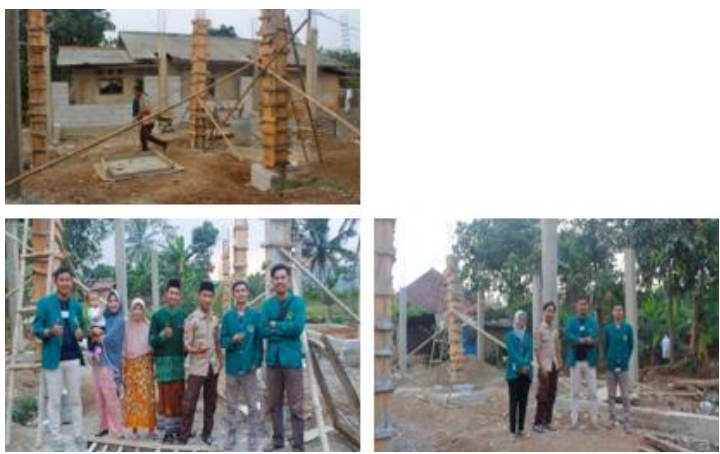

\section{n. Membantu Pembangunan Pondok} Pesantren Al-Qomariyah

Kegiatan ini dilakukan di Kampung Sindang Pala Desa Cibening, dalam pembangunan Ini Dilakukan pada bulan Juli 2018.

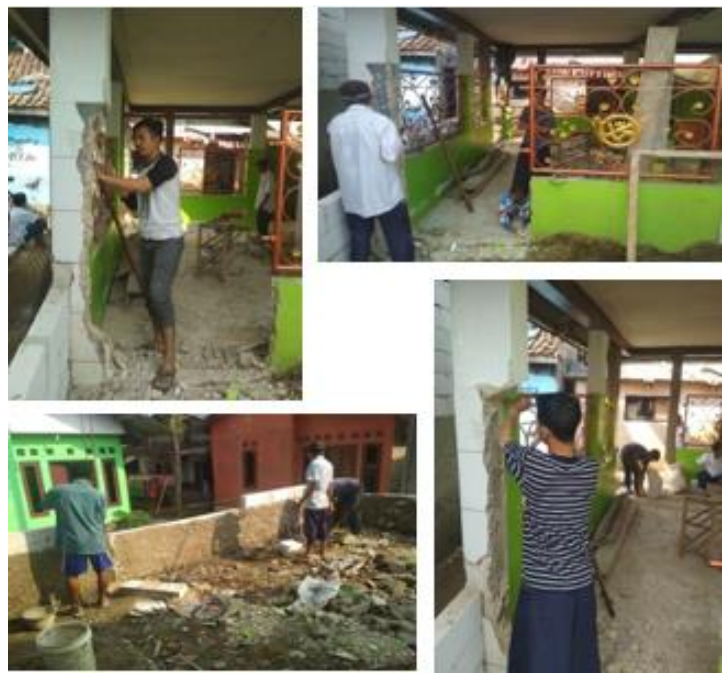

o. Membantu Pembangunan Majlis

Tempat : Kp. Sindang Pala Desa

Cibening RT. 04

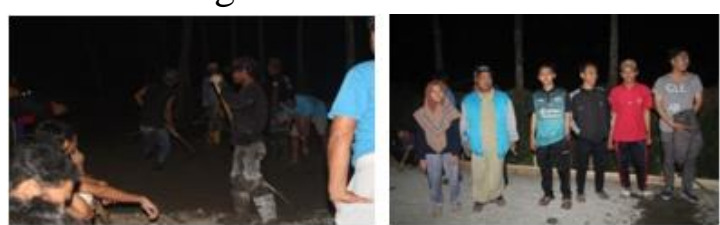

\section{p. Membantu Pengecoran Jalan}

Kegiatan Ini dilakukan pada tanggal 7 agustus 2018 dikampung Cikoan RW 09 Desa Cibening, dalam pengecoran dilakukan pada malam hari yang melibatkan pegawai Desa dan Warga RW 09. 


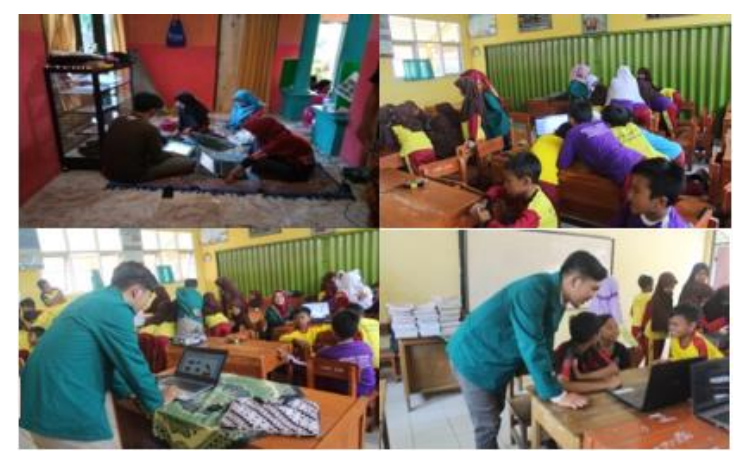

\section{q. Pelatihan TIK}

Kegiatan pelatihan TIK ini berlangsung di SDN Cibening 03 dengan sasaran siswa/i Sekolah Dasar kelas 5 sampai 6. Kegiatan pelatihan TIK dilakukan atas dasar kurangnya pengetahuan siswa/i tentang perkembangan teknologi dalam dunia pendidikan karena kurangnya fasilitas pendukung di sekolah. Pelatihan TIK ini mengangkat Microsoft Office Word dasar sebagai topik utama.

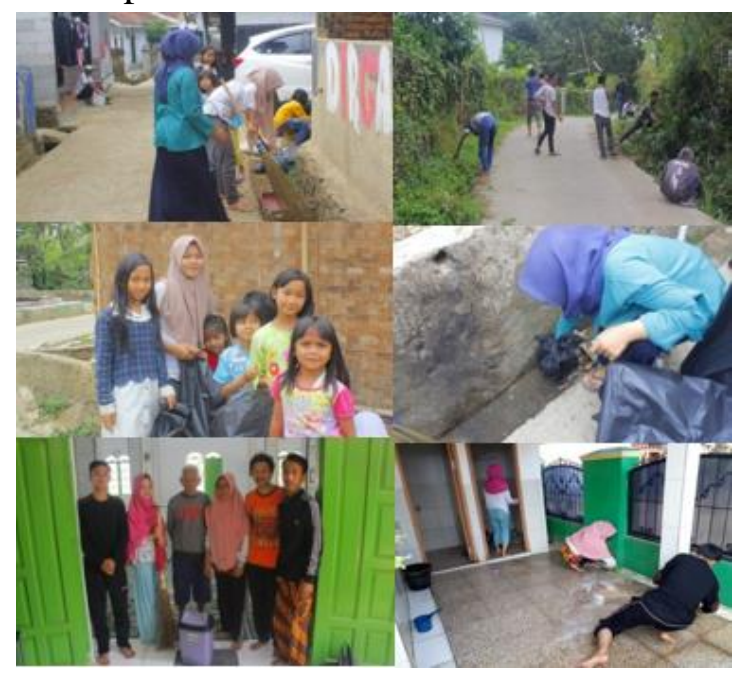

\section{KESIMPULAN}

KKN Tematik Terintegrasi merupakan kegiatan yang dapat menumbuhkan nilai-nilai, karena KKN meupakan pembelajaran di luar kampus dimana mahasiswa berada ditengah-tengah masyarakat, juga melalui KKN diharapkan mahasiswa mampu membantu dan mendampingi masyarakat untuk dapat

\section{r. Gotong Royong}

Kegiatan gotong royong diadakan di Masjid Al-A'la, Mushola RT 04, dan di sepanjang jalan RW $04 \mathrm{Kp}$. Sindang Pala. Kegiatan ini melibatkan warga secara langsung untuk membersihkan lingkungan sekitar. Kegiatan ini bertujuan untuk meningkatkan kesadarana warga akan pentingnya kebersihan dan membangun semangat warga dalam membersihkan ingkungan sekitar.

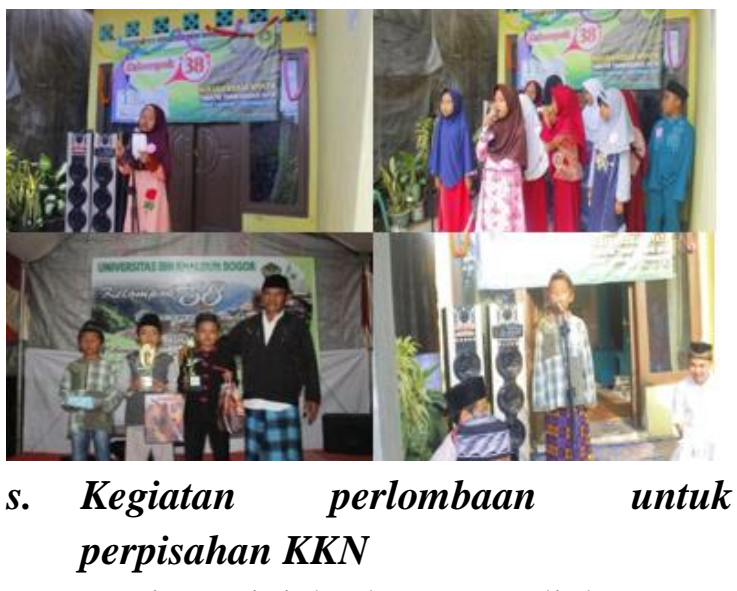

Kegiatan ini berlangsung di lapangan RW 03 dengan tujuan memberikan apresiasi kepada warga dan anak-anak di RW 04. Kegiatan yang melibatkan warga dan para aparat Desa ini meliputi 4 perlombaan yang ditujukan untuk anak- anak, yaitu lomba puisi, mewarnai, MTQ, dan Adzan.

memanfaatkan potensi yang ada dan dapat mengatasi permasalahan.

Dalam bidang pendidikan dapat dilihat di Kampung Sindang Pala Desa Cibening Kecamatan Pamijahan Kabupaten Bogor tepatnya di RW 04. Ada beberapa faktor yang menyebabkan hal tersebut terjadi diantaranya adalah, kurangnya perhatian orang tua terhadap waktu belajar 
anak, dan kurangnya konsentrasi siswa pada saat berada di sekolah dalam menerima materi pelajaran. Pemberian bimbingan belajar untuk membantu anak-anak di sekitar Kampung Sindang Pala dalam membantu mengerjakan pekerjaan rumah dan mengajarkan kesulitan belajar yang mereka hadapi.

Dalam bidang Kesehatan dapat dilihat dari kondisi yang ada di Desa Cibening sarana dan prasarana yang ada untuk kesehatan cukup memadai karena adanya beberapa klinik yang ada dipinggir jalan sekitar Desa Cibening.

Namun untuk sarana dan prasarana pelayanan kesehatan seperti puskesmas sangat jauh. Terutama dari Kampung Sindang Pala, jarak tempuhnya tidak dapat di akses dengan hanya berjalan kaki saja, namun harus menggunakan layanan angkutan umum.

Dalam bidang Ekonomi yang ada di Desa Cibening rata-rata mata pencahariannya adalah berjualan, berkebun, guru dan buruh harian lepas. Dari semua mata pencaharian yang ada penghasilan yang didapatkan tidak menentu, namun cukup untuk memenuhi kebutuhan seharihari.

Dalam bidang Lingkungan diliat dari kondisi yang ada sulitnya akses menemukan satu kampung ke kampung yang lainnya. Artinya tidak ada tanda jalan agar orang-orang yang berlalu lintas dapat dengan mudah untuk mencari kampung yang ada di Desa Cibening, termasuk Kampung Sindang Pala. Sehingga sama sekali tidak ada tanda yang menunjukkan apa nama kampung tersebut.

Keberhasilan KKN tidak lepas dari kerja sama antar mahasiswa/i dengan perangkat desa, masyarakat, serta semua pihak yang membantu dan mendukung kegiatan KKN. tanpa adanya kerja sama yang baik, program kerja KKN tidak akan berjalan dengan lancar. Dengan adanya mahasiswa/i KKN Kelompok 38, masyarakat terbantu dengan bertambahnya informasi dan ilmu pengetahuan yang mereka peroleh dari mahasiswa KKN Kelompok 38. adanya program kerja yang diadakan KKN Kelompok 38 masyarakat lebih aktif dalam melakukan kegiatankegiatan positif. kehadiran mahasiswa/i KKN Kelompok 38 pikiran masyarakat jauh lebih terbuka akan dunia luar dan mencontoh untuk lebih berfikir modern.

Kondisi dan situasi di Desa Cibening sangat mendukung untuk penerapan teori yang dipelajari di masa perkuliahan. 


\section{SARAN}

Dalam bidang pendidikan perlunya perhatian lebih dari orang tua terhadap kemajuan pendidikan anak. Adanya posko sebagai wadah untuk anak-anak dalam belajar.

Dalam bidang kesehatan memberikan kesadaran bagi masyarakat akan pentingnya lingkungan hidup yang bersih serta pola hidup yang sehat.

Dalam bidang ekonomi, Melakukan penjualan melalui Media Sosial (Medsos) seperti Instagram, Whatsapp, memperluas tempat produksi, menambah alat operasional produksi seperti mesin jahit, mesin potong, mesin dan mesin embos, dan menambah jumlah Sumber Daya Manusia (SDM). Adapun kami juga mengajarkan kepada anak-anak agar mulai terbiasa menabung sejak usia dini.

\section{REFERENSI}

Petunjuk Pelaksanaan KKN Tematik Terintegrasi 2018, LPPM UIKA BOGOR 2018, UIKA Press

Administrasi profil Desa Cibening

Administrasi profil Kp. Sindang Pala RT. 04 / RW. 04

http://journal.unj.ac.id/unj/index.php/jpm/a rticle/view/1781

https://media.neliti.com/media/publications /17909-ID-analisis-keputusan-
Dalam Bidang lingkungan, pemerintah desa harus memperhatikan wilayah kampung Sindang Pala, karena sulitnya akses jalan dan harus mengadakan plang petunjuk arah agar dapat memudahkan masyarakat menemukan daerah yang dituju (Kampung Sindang Pala).

\section{Luaran}

Luaran yang diharapkan dari pelaksanaan program ini adalah agar masyarakat umum mengetahui dan menyadari akan potensi besar yang dimiliki dari usaha home industry tas yang ada di Kampung Sindangpala Desa Cibening Kecamatan Pamijahan Kabupaten Bogor.

pembelian-konsumen-melalui-mediaonline-e-marketing.pdf

https://media.neliti.com/media/publications /124068-ID-none.pdf

http://sarahanisah25.blogspot.com/2016/10 /manfaat-pemasaran-online$\underline{\text { manfaat.html }}$

https://eksplorasidatasaham.wordpress.com /2018/03/01/memahami-pentingnyakepuasan-dan-loyalitas-konsumen/ 